\title{
Pengaruh Konsentrasi Etanol dan Waktu Ekstraksi Terhadap Aktivitas Antioksidan Ekstrak Daun Buangit (Cleome gynandra) Dengan Metode Microwave Assisted Extraction
}

\section{Effect of Ethanol Concentration and Extraction Time on Antioxidant Activity of Buangit Leaves Extract (Cleome gynandra) Using Microwave Assisted Extraction}

\author{
Clara Sania Krisanta ${ }^{1}$, Ni Luh Ari Yusasrini ${ }^{* *}$, I Nengah Kencana Putra ${ }^{1}$ \\ Program Studi Teknologi Pangan, Fakultas Teknologi Pertanian, Universitas Udayana \\ Kampus Bukit Jimbaran, Badung-Bali \\ *Penulis korespondensi: Ni Luh Ari Yusasrini, Email: ariyusasrini@unud.ac.id
}

\begin{abstract}
Buangit leaves (Cleome gynandra) contain bioactive components such as phenol compounds, flavonoids and vitamin C, which can act as antioxidant. This research aims were to determine the effect of ethanol concentration and extraction time using Microwave Assisted Extraction (MAE) on antioxidant activity and to obtain the appropriate ethanol concentration and extraction time that can produce the highest antioxidant activity of buangit leaves extract. The research was designed using a completely randomized factorial design, which consisted of two factor. The first factor was ethanol concentration (ethanol 60\%, 70\%, 80\% and 90\%) and the second factor was the extraction time (3,5 and 7 minutes). The entire treatment was repeated 2 times to obtain 24 units of experiments. Data were analyzed by analysis of variance and if the treatment had a significant effect, followed by Duncan Multiple Range Test. This research showed that the interaction between ethanol concentration and time extraction had significant effects on total flavonoids and antioxidant activity, but it had non-significant effects on total phenol and total vitamin C. However, ethanol concentration and time extraction had significant effects on total phenols, total flavonoids, total vitamin $\mathrm{C}$ and antioxidant activity. The results showed that MAE of buangit leaves using $70 \%$ ethanol concentration for 7 minutes was the best treatment on this research, which can produce $18.52 \pm 0.64 \mathrm{mg} \mathrm{GAE} / \mathrm{g}$ of total phenols, $19.28 \pm 0.18 \mathrm{mg} \mathrm{QE} / \mathrm{g}$ of total flavonoid, $89.85 \pm 5.30 \mathrm{mg} \mathrm{AAE} / \mathrm{g}$ of vitamin $\mathrm{C}$ and antioxidant activity based on IC50 value at $131.85 \pm 0.71 \mathrm{ppm}$
\end{abstract}

Keywords: Buangit, MAE, Ethanol, Time Extraction, Antioxidant Activity

\section{PENDAHULUAN}

Buangit (Cleome gynandra) merupakan sayuran liar yang pada umumnya tumbuh di daerah tropis dan tersebar luas di Afrika dan beberapa negara Asia. Buangit menjadi bahan baku dalam pembuatan makanan khas Singaraja yaitu Jukut Buangit. Selain digunakan sebagai makanan keseharian, daun buangit juga digunakan sebagai pengobatan tradisional untuk mengobati pusing, migrain, demam, diare, konstipasi, inflamasi, pneumonia, rematik, artitis dan lainnya (Kwarteng et al., 2018). Daun buangit mengandung flavonoid, fenol, alkaloid, saponin, tanin dan glikosida (Mangaiyarkarasi dan Ilyas, 2015). Anbazhagi et al. (2008) melaporkan bahwa setiap $100 \mathrm{~g}$ bubuk daun buangit mengandung total fenol sebesar 321 mg GAE, total flavonoid sebesar $207 \mathrm{mg}$ QE dan vitamin C sebesar $70 \mathrm{mg}$ AAE. Fenol, flavonoid dan vitamin $\mathrm{C}$ dapat berperan sebagai antioksidan. Mibei et al. (2012) melaporkan daun buangit memiliki aktivitas antioksidan sebesar 92,8\% dengan nilai $\mathrm{IC}_{50}$ sebesar $0,04 \mathrm{mg} / \mathrm{ml}$. Antioksidan merupakan senyawa yang dibutuhkan tubuh untuk menetralisir radikal bebas dan mencegah kerusakan yang ditimbulkannya.

Antioksidan dalam daun buangit dapat diperoleh melalui proses ekstraksi. Ekstraksi dapat dilakukan dengan berbagai metode, salah satunya yaitu microwave assisted extraction (MAE). MAE 
merupakan ekstraksi yang memanfaatkan radiasi gelombang mikro untuk mempercepat ekstraksi senyawa target melalui pemanasan pelarut secara cepat dan efisien (Jain et al., 2009). Keunggulan MAE yaitu mudah untuk dioperasikan dan penggunaan pelarut yang relatif sedikit dibandingkan dengan metode lainnya. Mekanisme kerja dari MAE yaitu pergerakan molekuler secara cepat dengan cara migrasi ion dan rotasi dipol yang disebabkan oleh gelombang mikro sehingga menghasilkan panas dan memicu terjadinya kerusakan sel maupun jaringan dan senyawa target keluar dari sel (Delazar et al.,2012).

Faktor yang mempengaruhi kerja MAE yaitu polaritas pelarut dan waktu ekstraksi. Pemilihan pelarut ditentukan oleh kelarutan senyawa target dan sifat penyerapan gelombang mikro (Destandau et al., 2015). Efisiensi ekstraksi dipengaruhi oleh polaritas pelarut dikarenakan pelarut hanya akan mengekstrak senyawa yang memiliki polaritas yang sama (like dissolves like) (Hismath et al., 2011). Ekstraksi daun buangit dengan berbagai jenis pelarut menunjukkan bahwa pelarut etanol $70 \%$ menghasilkan hasil ekstraksi terbaik diikuti dengan pelarut etanol 95\%, air dan aseton (Anbazhagi et al., 2008). Hal ini menunjukkan bahwa pelarut etanol memiliki kelarutan yang hampir sama dengan senyawa bioaktif daun buangit, namun dapat dimungkinkan bahwa konsentrasi etanol 70\% belum menjadi titik optimal dalam ekstraksi senyawa target menggunakan metode MAE. Optimasi ekstrasi dalam metode MAE juga bergantung pada kapasitas pelarut untuk menyerap energi gelombang mikro, yang dipengaruhi oleh sifat dielektrik pelarut yaitu nilai konstanta dielektrik dan faktor disipasi pelarut (Veggi et al., 2013). Sifat dari larutan dapat diubah dengan menggabungkannya dengan pelarut lain, seperti penggabungan dengan air yang memiliki nilai dielektrik tinggi maka akan meningkatkan kepolaran pelarut tersebut. Konsentrasi pelarut dapat divariasikan untuk menunjukkan perbedaan pengaruh akibat perubahan polaritas sehingga mempengaruhi kelarutan senyawa bioaktif dalam ekstraksi menggunakan metode MAE.

Waktu ekstraksi berpengaruh terhadap optimasi pelarut dengan bantuan gelombang mikro untuk mengeluarkan senyawa yang akan diekstrak dari dalam matriks. Waktu ekstraksi yang semakin lama menyebabkan penurunan kadar senyawa target yang disebabkan oleh lamanya paparan gelombang mikro yang dapat memicu terjadinya overheating dan degradasi senyawa thermolabil. Waktu ekstraksi yang terlalu singkat dapat menyebabkan pembebasan senyawa di dalam matrik belum optimal sehingga belum menghasilkan hasil ekstraksi yang optimal (Veggi et al., 2013). Kristanti et al. (2019) melaporkan kombinasi antara waktu ekstraksi dan konsentrasi etanol dalam ekstraksi rambut jagung menunjukkan bahwa semakin tinggi waktu ekstraksi dan konsentrasi etanol maka semakin tinggi pula aktivitas antioksidan yang dihasilkan. Oleh sebab itu, penelitian ini bertujuan untuk mengetahui pengaruh konsentrasi etanol dan waktu ekstraksi dengan metode MAE serta mendapatkan kombinasi konsentrasi etanol dan waktu ekstraksi yang tepat sehingga dihasilkan ekstrak daun buangit dengan aktivitas antioksidan tertinggi. 


\section{METODE PENELITIAN}

\section{Tempat dan Waktu Penelitian}

Penelitian ini dilakukan di Laboratorium Pengolahan Pangan dan Laboratorium Analisis Pangan Program Studi Teknologi Pangan, Fakultas Teknologi Pertanian, Universitas Udayana, Denpasar, Bali pada bulan Agustus - September 2020.

\section{Bahan dan Alat}

Bahan utama dalam penelitian ini adalah daun buangit yang diperoleh dari kebun buangit, Desa Bungkulan, Singaraja dengan karakteristik daun muda yang terletak pada pucuk diikuti dengan keempat cabang daun dibawahnya $(\mathrm{P}+4)$ dan tidak mengalami kerusakan. Bahan lain yang digunakan yaitu etanol (Merck), asam galat (Sigma), aquadest, reagen Folin-Ciocalteu (Merck), $\mathrm{Na}_{2} \mathrm{CO}_{3}$ (Merck), DPPH (SigmaAldrich), $\mathrm{AlCl}_{3} 6 \mathrm{H}_{2} \mathrm{O}$ (Merck), kuersetin (Sigma), asam sulfat (Merck), sodium fosfat (Merck) dan ammonium molibdat (Merck) dan asam askorbat (Merck).

Peralatan yang digunakan yaitu microwave Samsung ME371k yang telah dimodifikasi, oven (Maksindo), ayakan 60 mesh, blender (Phillips), neraca analitik (Shimadzu ATY224), round flaks $500 \mathrm{~mL}$, botol kaca, kertas saring Whatman No.1, gelas beaker, erlenmeyer, gelas ukur, labu ukur, pipit tetes, pipet mikro, pipet volume, bola hisap, tabung reaksi, vortex, watherbath (J.P Selecta), spektrofotometer UV Vis (Genesys 10s Uv-Vis), corong, spatulla, aluminium foil dan baskom.

\section{Rancangan Penelitian}

Rancangan penelitian yang digunakan yaitu Rancangan Acak Lengkap faktorial (RAL faktorial) yang terdiri dari dua faktor. Faktor pertama yaitu konsentrasi etanol (S) dengan 4 taraf yaitu etanol $60 \%\left(\mathrm{~S}_{1}\right)$, etanol $70 \%\left(\mathrm{~S}_{2}\right)$, etanol $80 \%$ $\left(\mathrm{S}_{3}\right)$ dan etanol $90 \%\left(\mathrm{~S}_{4}\right)$. Faktor kedua yaitu waktu ekstraksi (t) dengan 3 taraf yaitu 3 menit $\left(\mathrm{t}_{1}\right), 5$ menit $\left(t_{2}\right)$ dan 7 menit $\left(t_{3}\right)$. Kedua faktor tersebut dikombinasikan sehingga diperoleh 12 kombinasi perlakuan yaitu $\left(\mathrm{S}_{1} \mathrm{t}_{1}\right),\left(\mathrm{S}_{1} \mathrm{t}_{2}\right),\left(\mathrm{S}_{1} \mathrm{t}_{3}\right),\left(\mathrm{S}_{2} \mathrm{t}_{1}\right),\left(\mathrm{S}_{2} \mathrm{t}_{2}\right)$, $\left(\mathrm{S}_{2} \mathrm{t}_{3}\right),\left(\mathrm{S}_{3} \mathrm{t}_{1}\right),\left(\mathrm{S}_{3} \mathrm{t}_{2}\right),\left(\mathrm{S}_{3} \mathrm{t}_{3}\right),\left(\mathrm{S}_{4} \mathrm{t}_{1}\right),\left(\mathrm{S}_{4} \mathrm{t}_{2}\right),\left(\mathrm{S}_{4} \mathrm{t}_{3}\right) \mathrm{dan}$ masing-masing diulang sebanyak 2 kali sehingga diperoleh 24 unit percobaan.

Data yang diperoleh dari hasil penelitian dianalisis menggunakan sidik ragam dengan taraf keyakinan $95 \%$ dan apabila terdapat pengaruh nyata dari perlakuan yang diberikan maka dilakukan uji lanjut Duncan Multiple Range Test (DMRT).

\section{Pelaksanaan Penelitian}

\section{Persiapan Bahan}

Daun buangit dicuci dengan air mengalir untuk menghilangkan kotorannya hingga bersih lalu ditiriskan. Setelah itu, daun buangit dikeringkan dengan oven pada suhu $50^{\circ} \mathrm{C}$ selama \pm 8 jam, hingga daun buangit mudah untuk dipatahkan. Daun kering dihaluskan dengan blender kemudian diayak menggunakan ayakan 60 mesh sehingga dihasilkan bubuk daun buangit. Bubuk tersebut ditimbang beratnya untuk mendapatkan berat akhir kemudian disimpan pada tempat kering (Moyo et al.,2016).

\section{Proses Ekstraksi}

Proses ektraksi dilakukan dengan metode MAE seperti yang dilakukan oleh Zecović et al. (2016) yang telah dimodifikasi. Ekstraksi menggunakan daya sebesar 450 W dan perbandingan sampel dengan pelarut yang 
digunakan yaitu 1:10 (b/v). Bubuk daun buangit sebanyak $10 \mathrm{~g}$ dilarutkan dalam $100 \mathrm{ml}$ pelarut etanol pada konsentrasi sesuai perlakuan di dalam round flaks berukuran $500 \mathrm{ml}$. Setelah itu, larutan tersebut diekstraksi menggunakan microwave dengan waktu ekstraksi sesuai dengan perlakukan. Hasil ekstraksi disaring menggunakan kertas saring Whatman No.1. Filtrat disimpan dalam botol amber pada suhu $4^{\circ} \mathrm{C}$, kemudian dianalisis total fenol, total flavonoid, vitamin $\mathrm{C}$ dan aktivitas antioksidannya.

\section{Paramenter yang diamati}

Variabel yang diamati dalam penelitian ini adalah total fenol dengan metode Folin-Ciocalteu (Sakanaka et al., 2005), total flavonoid dengan metode kolorimeter- $\mathrm{AlC}_{3}$ (Guntarti et al., 2017), total vitamin $\mathrm{C}$ dengan metode fosfomolibdenum (Papoutsis et al., 2016) dan aktivitas antioksidan berdasarkan nilai IC50 dengan metode DPPH (Hanani et al., 2005).

\section{HASIL DAN PEMBAHASAN}

\section{Total Fenol Ekstrak Daun Buangit}

Hasil sidik ragam menunjukkan bahwa interaksi antara konsentrasi etanol dan waktu ekstraksi tidak berpengaruh nyata $(\mathrm{P}>0,05)$ terhadap total fenol ekstrak daun buangit. Namun, konsentrasi etanol dan waktu ekstraksi berpengaruh nyata $(\mathrm{P}<0,05)$ terhadap total fenol ekstrak daun buangit. Adapun hasil analisis total fenol ekstrak daun buangit dapat dilihat pada Tabel 1.

Tabel 1. Total fenol ekstrak daun buangit (mg GAE/g)

\begin{tabular}{lcccc}
\hline \multirow{2}{*}{ Konsentrasi Etanol } & \multicolumn{3}{c}{ Waktu Ekstraksi } & \multirow{2}{*}{ Rata-rata } \\
\cline { 2 - 4 } & 3 menit & 5 menit & 7 menit & \\
\hline Etanol $60 \%$ & $12,61 \pm 1,60$ & $15,37 \pm 2,13$ & $15,80 \pm 1,87$ & $14,59 \pm 2,13 \mathrm{ab}$ \\
Etanol $70 \%$ & $12,96 \pm 0,23$ & $15,86 \pm 0,20$ & $18,52 \pm 0,64$ & $15,78 \pm 2,51 \mathrm{a}$ \\
Etanol $80 \%$ & $11,35 \pm 0,58$ & $14,09 \pm 0,09$ & $15,74 \pm 2,42$ & $13,73 \pm 2,28 \mathrm{~b}$ \\
Etanol 90\% & $9,76 \pm 0,15$ & $10,77 \pm 0,23$ & $11,93 \pm 0,23$ & $10,82 \pm 0,98 \mathrm{c}$ \\
\hline Rata-rata & $11,67 \pm 14,9 \mathrm{c}$ & $14,02 \pm 2,27 \mathrm{~b}$ & $15,50 \pm 2,78 \mathrm{a}$ & \\
\hline
\end{tabular}

Keterangan: Nilai rata-rata \pm standar deviasi $(\mathrm{n}=2)$. Huruf yang berbeda di belakang nilai rata-rata pada baris atau kolom yang sama menunjukkan perbedaan yang nyata $(\mathrm{P}<0,05)$.

Ekstraksi daun buangit dengan etanol 70\% selama 7 menit memiliki total fenol tertinggi dengan nilai sebesar 18,52 $\pm 0,64 \mathrm{mg}$ GAE/g. Kadar fenol terendah ditunjukkan oleh hasil ekstraksi daun buangit dengan etanol 90\% selama 3 menit yaitu sebesar 9,76 $\pm 0,15 \mathrm{mg} \mathrm{GAE} / \mathrm{g}$. Hasil penelitian menunjukkan bahwa semakin lama waktu ekstraksi maka semakin tinggi total fenol yang didapatkan. Peningkatan waktu ekstraksi menyebabkan lamanya durasi kontak pelarut dengan bahan yang diekstrak, sehingga pelarut akan optimal untuk menarik senyawa fenol keluar dari bahan tersebut. Pada umumnya hasil ekstraksi dipengaruhi oleh waktu ekstraksi di mana semakin lama waktu ekstraksi maka semakin tinggi hasil ekstraksi hingga titik optimal (Delazar et al., 2012). Hal ini sesuai dengan penelitian Ghakerani et al. (2012) yang menyatakan bahwa semakin tinggi waktu ekstraksi dengan metode MAE pada daun 
blueberry menghasilkan total fenol dan flavonoid yang semakin tinggi.

Hasil penelitian menunjukkan bahwa terjadi peningkatan total fenol hingga konsentrasi etanol $70 \%$, namun seiring tingginya konsentrasi etanol maka semakin rendah total fenol yang didapatkan. Suatu pelarut akan efektif mengekstrak senyawa target apabila memiliki polaritas yang sama dengan pelarut yang digunakan (like dissolves like) (Hismath et al., 2011). Hasil penelitian menunjukkan bahwa adanya kesamaan polaritas antara senyawa fenol ekstrak daun buangit dengan etanol $70 \%$ yang ditunjukkan dari tingginya senyawa fenol yang terlarut. Etanol memiliki gugus hidroksil yang dapat membentuk ikatan hidrogen dengan gugus hidroksil senyawa fenol sehingga terjadi peningkatan senyawa fenol dalam etanol (Prayitno et al., 2016). Hasil penelitian ini didukung oleh Anbazhagi et al. (2011) yang melaporkan bahwa ekstraksi daun buangit metode sokletasi dengan etanol 70\% menghasilkan senyawa fenol sebesar $321 \pm 2,65$ mg GAE/100 g dan lebih tinggi dibandingkan dengan senyawa fenol yang terekstrak oleh etanol 90\% (<100 mg GAE/100g). Penelitian lainnya tentang ekstraksi daun blueberry dengan metode MAE oleh Gharekhani et al. (2012) melaporkan bahwa konsentrasi etanol berpengaruh terhadap total fenol yang terekstrak, di mana terjadi kenaikan total fenol pada konsentrasi etanol 10$50 \%$ sebesar 54,3-84,4 mg GAE/g, namun mengalami penurunan seiring dengan tingginya konsentrasi etanol. Pernyataan tersebut mendukung hasil total fenol pada ekstrak daun buangit di mana semakin tinggi konsentrasi etanol maka semakin rendah kadar fenol yang didapatkan.

Daun buangit mengandung senyawa fenol berupa asam p-kumarat, asam ferulat, asam kafeat, dimethoxycinnamoyl glucuronide, homovanillic glucoside, asam galat, asam protokatekuat, esculentin dan vanillin (Chandradevan et al., 2020). Moyo et al. (2016) melaporkan bahwa daun buangit yang mendapat perlakuan pengeringan selama 8 jam pada suhu $50^{\circ} \mathrm{C}$ kemudian diekstraksi metode UAE dengan metanol $80 \%$ memiliki total fenol sebesar 965,41 $\pm 53,07 \mathrm{mg} \mathrm{GAE} / 100 \mathrm{~g}$. Hal ini menunjukkan bahwa ekstraksi metode MAE dengan pelarut etanol $70 \%$ selama 7 menit dapat menghasilkan total fenol yang lebih tinggi dibandingkan dengan penelitian sebelumnya.

\section{Total Flavonoid Ekstrak Daun Buangit}

Hasil sidik ragam menunjukkan bahwa interaksi antara konsentrasi etanol dan waktu ekstraksi berpengaruh nyata $(\mathrm{P}<0,05)$ terhadap total flavonoid ekstrak daun buangit. Adapun hasil analisis total flavonoid ekstrak daun buangit dapat dilihat pada Tabel 2.

Ekstrasi daun buangit dengan etanol 90\% selama 7 menit memiliki total flavonoid tertinggi dengan nilai sebesar 35,54 $\pm 0,83 \mathrm{mg}$ QE/g. Kadar flavonoid terendah ditunjukkan oleh hasil ekstraksi daun buangit dengan etanol $60 \%$ selama 3 menit yaitu sebesar 14,22 $\pm 0,07 \mathrm{mg}$ QE/g. Hasil penelitian menunjukkan bahwa senyawa flavonoid yang terekstrak dari daun buangit memiliki sifat yang cenderung kurang polar, sehingga mudah larut dalam pelarut dengan kepolaran yang lebih rendah. Semakin tinggi konsentrasi etanol maka 
semakin rendah polaritas pelarut karena menurunnya campuran air dalam pelarut tersebut. Senyawa aglikon flavonoid berupa isoflavon, flavon, flavanon, dan flavanol memiliki sifat yang cenderung mudah larut pada pelarut non-aquades atau pelarut dengan kepolaran rendah (Stoica et al., 2014). Oleh sebab itu, kemungkinan terjadi pembebasan aglikon flavonoid yang efektif pada penelitian ini seiring dengan tingginya konsentrasi etanol. Penelitian ini didukung oleh Gharekhani et al. (2012) yang melaporkan bahwa hasil ekstraksi daun blueberry dengan metode MAE memiliki total flavonoid yang semakin meningkat seiring dengan kenaikan konsentrasi etanol hingga didapatkan total flavonoid sebesar 14,8 mg QE/g pada konsentrasi etanol $100 \%$.

Tabel 2. Total flavonoid ekstrak daun buangit (mg QE/g)

\begin{tabular}{lccc}
\hline \multirow{2}{*}{ Konsentrasi Etanol } & \multicolumn{3}{c}{ Waktu Ekstraksi } \\
\cline { 2 - 4 } Etanol $60 \%$ & 3 menit & 5 menit & 7 menit \\
& $14,22 \pm 0,07 \mathrm{c}$ & $15,42 \pm 0,04 \mathrm{~b}$ & $16,11 \pm 0,22 \mathrm{a}$ \\
Etanol $70 \%$ & $(\mathrm{~d})$ & $(\mathrm{d})$ & $(\mathrm{d})$ \\
& $18,60 \pm 0,72 \mathrm{a}$ & $19,06 \pm 0,29 \mathrm{a}$ & $19,28 \pm 0,18 \mathrm{a}$ \\
Etanol $80 \%$ & $(\mathrm{c})$ & $(\mathrm{c})$ & $(\mathrm{c})$ \\
& $23,07 \pm 0,43 \mathrm{c}$ & $25,94 \pm 0,47 \mathrm{~b}$ & $32,27 \pm 1,29 \mathrm{a}$ \\
Etanol $90 \%$ & $(\mathrm{~b})$ & $(\mathrm{b})$ & $(\mathrm{b})$ \\
& $30,67 \pm 0,90 \mathrm{c}$ & $32,95 \pm 0,54 \mathrm{~b}$ & $35,54 \pm 0,83 \mathrm{a}$ \\
& $(\mathrm{a})$ & $(\mathrm{a})$ & (a) \\
\hline
\end{tabular}

Keterangan: Nilai rata-rata \pm standar deviasi $(\mathrm{n}=2)$. Huruf yang berbeda di belakang/di bawah nilai rata-rata pada baris/kolom yang sama menunjukkan perbedaan yang nyata $(\mathrm{P}<0,05)$.

Selain kelarutan senyawa, difusitas senyawa target juga dipengaruhi oleh waktu ekstraksi. Hasil penelitian menunjukkan bahwa semakin lama waktu ekstraksi maka semakin tinggi total flavonoid yang didapatkan. Waktu ekstraksi berpengaruh terhadap optimasi pelarut dengan bantuan gelombang mikro untuk mengeluarkan senyawa yang akan diekstrak dari dalam matrik, di mana waktu yg terlalu singkat dapat menyebabkan belum optimalnya pembebasan senyawa target oleh pelarut (Veggi et al., 2013). Semakin lama waktu ekstraksi maka semakin tinggi pula suhu di dalam matriks. Peningkatan suhu dipengaruhi oleh kemampuan pelarut untuk mengubah paparan gelombang elektromagnetik yang diterima menjadi energi panas yang akan mendegradasi dinding sel sehingga senyawa target dapat keluar dari matriks (Kamaluddin et al., 2014)

Buangit mengandung katekin, luteolin, proantosianidin, kuersetin, kaempferol, isokaempferide, jaceosidin, penduletin, axillarin, chrysosplenetin dan turunan flavon lainnya (Chandradevan et al., 2020; Lokesha, 2018). Widodo dan Pratiwi (2018) melaporkan bahwa Cleome gynandra yang diekstrak menggunakan metode maserasi dengan etanol $96 \%$ mengandung total flavonoid sebesar 4,778 $\pm 0,522 \mathrm{mg} \mathrm{QE} / \mathrm{g}$. Pengeringan daun buangit selama 8 jam dengan suhu $50^{\circ} \mathrm{C}$, kemudian diekstrak metode UAE dengan metanol $80 \%$ menghasilkan total flavonoid sebesar 150,24 $\pm 10.59 \mathrm{mg}$ QE/100g (Moyo et al.,2016). Hal ini menunjukkan bahwa ekstraksi metode MAE dengan etanol $90 \%$ selama 7 menit 
menghasilkan total flavonoid yang lebih tinggi dibandingkan dengan penelitian sebelumnya.

\section{Total Vitamin C Ekstrak Daun Buangit}

Hasil sidik ragam menunjukkan bahwa interaksi antara konsentrasi etanol dan waktu ekstraksi tidak berpengaruh nyata $(\mathrm{P}>0,05)$ terhadap total vitamin $\mathrm{C}$ ekstrak daun buangit. Namun, konsentrasi etanol dan waktu ekstraksi berpengaruh nyata $(\mathrm{P}<0,05)$ terhadap total vitamin $\mathrm{C}$ ekstrak daun buangit. Adapun hasil analisis total vitamin $\mathrm{C}$ ekstrak daun buangit dapat dilihat pada Tabel 3.

Tabel 3. Total vitamin C ekstrak daun buangit (mg AAE/g)

\begin{tabular}{lcccc}
\hline \multirow{2}{*}{ Konsentrasi Etanol } & \multicolumn{3}{c}{ Waktu Ekstraksi } & \multirow{2}{*}{ Rata-rata } \\
\cline { 2 - 4 } & 3 menit & 5 menit & 7 menit & \\
\hline Etanol $60 \%$ & $57,70 \pm 4,90$ & $68,48 \pm 9,02$ & $82,45 \pm 3,32$ & $69,54 \pm 12,10 \mathrm{~b}$ \\
Etanol $70 \%$ & 70,91 & $76,26 \pm 3,85$ & $89,85 \pm 5,30$ & $79,01 \pm 9,21 \mathrm{a}$ \\
Etanol $80 \%$ & $71,95 \pm 2,26$ & $76,73 \pm 2,12$ & $90,88 \pm 0,40$ & $79,85 \pm 8,92 \mathrm{a}$ \\
Etanol 90\% & $73,07 \pm 0,40$ & $77,85 \pm 5,03$ & $93,42 \pm 1,86$ & $81,45 \pm 9,81 \mathrm{a}$ \\
\hline Rata-rata & $68,41 \pm 6,97 \mathrm{c}$ & $74,83 \pm 5,81 \mathrm{~b}$ & $89,15 \pm 5,01 \mathrm{a}$ & \\
\hline
\end{tabular}

Keterangan: Nilai rata-rata \pm standar deviasi $(\mathrm{n}=2)$. Huruf yang berbeda di belakang nilai rata-rata pada baris atau kolom yang sama menunjukkan perbedaan yang nyata $(\mathrm{P}<0,05)$.

Ekstraksi daun buangit dengan etanol 90\% selama 7 menit memiliki total vitamin $\mathrm{C}$ tertinggi dengan nilai sebesar 93,42 $\pm 1,86 \mathrm{mg} \mathrm{AAE} / \mathrm{g}$. Total vitamin $\mathrm{C}$ terendah ditunjukkan oleh hasil ekstraksi daun buangit dengan etanol $60 \%$ selama 3 menit yaitu sebesar 57,70 $\pm 4,90 \mathrm{mg} \mathrm{AAE} / \mathrm{g}$. Hasil penelitian menunjukkan bahwa vitamin $\mathrm{C}$ dalam ekstrak daun buangit cenderung lebih efektif terekstrak pada pelarut dengan kepolaran yang lebih rendah seiiring dengan lamanya waktu ekstraksi. Vitamin C dapat larut dalam air, metanol dan etanol. Etanol merupakan senyawa yang memiliki 2 gugus fungsi yaitu non polar (R') dan polar $(-\mathrm{OH})$, sehingga berpotensi dalam mengekstraksi senyawa polar hingga kurang polar (Widyawati, 2005). Berdasarkan nilai rata-rata konsentrasi etanol, menunjukan bahwa vitamin $\mathrm{C}$ ekstrak daun buangit memiliki kepolaran yang cenderung sama dengan etanol 90\%, meskipun secara statistik tidak berbeda nyata dengan etanol $70 \%$ dan etanol $80 \%$, namun berbeda nyata dengan etanol $60 \%$. Suatu pelarut akan efektif mengekstrak senyawa target apabila memiliki polaritas yang sama dengan pelarut yang digunakan (like dissolves like) (Hismath et al., 2011). Avriani dan Parnanto (2013) melaporkan bahwa vitamin $\mathrm{C}$ pada buah salak memiliki kepolaran yang sama dengan pelarut etanol sehingga lebih efektif terekstrak pada pelarut etanol daripada pelarut air. Pernyataan tersebut mendukung hasil penelitian, di mana peningkatan polaritas seiring meningkatnya konsentrasi air dalam pelarut menyebabkan penurunan kelarutan vitamin C dalam pelarut. Verdiana et al. (2018) juga melaporkan bahwa pelarut dengan kepolaran lebih rendah dapat mengekstrak vitamin $\mathrm{C}$ lebih efektif, di mana ekstrak aseton menghasilkan total vitamin $\mathrm{C}$ tertinggi diikuti dengan 
etanol $>$ metanol $>$ aquades pada ekstrak kulit buah lemon.

Hasil penelitian menunjukkan bahwa semakin tinggi waktu ekstraksi maka semakin tinggi total vitamin $\mathrm{C}$ yang dihasilkan. Lama waktu ekstraksi akan meningkatkan panas yang dihasilkan akibat lamanya paparan gelombang mikro. Pemanasan oleh gelombang mikro memicu terjadinya penguapan air intraseluler yang akan menghasilkan tekanan di dalam sel. Tekanan tersebut akan menyebabkan pecahnya dinding sel sehingga dapat meningkatkan senyawa target terdifusi ke pelarut. Namun, waktu ekstraksi yang melebihi waktu optimal mengakibatkan terjadinya degradasi senyawa target oleh panas tersebut (Aulia dan Widjanarko, 2018).

Buangit dalam penelitian ini memiliki kandungan vitamin $\mathrm{C}$ yang lebih tinggi dibandingan dengan total vitamin $\mathrm{C}$ yang dilaporkan oleh peneliti terdahulu. Sogbohossou et al. (2019) melaporkan bahwa daun buangit di wilayah Asia Tenggara, Afrika Selatan, Afrika Timur dan Afrika Barat memiliki total vitamin C berkisar sebesar 173,7 $\mu \mathrm{g} / \mathrm{g}-849,1 \pm 272,8 \mu \mathrm{g} / \mathrm{g}$. Total vitamin $\mathrm{C}$ daun buangit di Zambia yaitu sebesar 1,06-1,4 mg/g (Jiménez-Aquilar dan Grusak, 2015).

\section{Aktivitas Antioksidan}

Hasil sidik ragam menunjukkan bahwa interaksi antara konsentrasi etanol dan waktu ekstraksi berpengaruh nyata $(\mathrm{P}<0,05)$ terhadap aktivitas antioksidan ekstrak daun buangit. Adapun hasil analisis aktivitas antioksidan berdasarkan nilai IC50 ekstrak daun buangit dapat dilihat pada Tabel 4.

Tabel 4. Aktivitas antioksidan berdasarkan nilai IC50 ekstrak daun buangit (ppm)

\begin{tabular}{lccc}
\hline Konsentrasi Etanol & \multicolumn{3}{c}{ Waktu Ekstraksi } \\
\cline { 2 - 4 } & 3 menit & 5 menit & 7 menit \\
\hline \multirow{2}{*}{ Etanol $60 \%$} & $149,21 \pm 2,82 \mathrm{a}$ & $147,77 \pm 0,01 \mathrm{a}$ & $132,02 \pm 0,86 \mathrm{~b}$ \\
& $(\mathrm{~b})$ & $(\mathrm{b})$ & $(\mathrm{b})$ \\
Etanol $70 \%$ & $154,74 \pm 6,69 \mathrm{a}$ & $138,79 \pm 8,52 \mathrm{ab}$ & $131,85 \pm 0,71 \mathrm{~b}$ \\
& $(\mathrm{~b})$ & $(\mathrm{b})$ & $(\mathrm{b})$ \\
Etanol $80 \%$ & $220,40 \pm 7,29 \mathrm{a}$ & $197,42 \pm 8,95 \mathrm{ab}$ & $162,40 \pm 18,72 \mathrm{~b}$ \\
& $(\mathrm{a})$ & $(\mathrm{a})$ & $(\mathrm{ab})$ \\
Etanol $90 \%$ & $251,63 \pm 20,53 \mathrm{a}$ & $211,52 \pm 11,7 \mathrm{ab}$ & $184,12 \pm 12,63 \mathrm{~b}$ \\
& $($ a) & $($ a) & (a) \\
\hline
\end{tabular}

Keterangan: Nilai rata-rata \pm standar deviasi $(\mathrm{n}=2)$. Huruf yang berbeda di belakang/di bawah nilai rata-rata pada baris/kolom yang sama menunjukkan perbedaan yang nyata $(\mathrm{P}<0,05)$.

Ekstraksi daun buangit dengan etanol 90\% selama 3 menit memiliki aktivitas antioksidan terendah dengan nilai IC50 sebesar 251,63 $\pm 20,53$ ppm. Aktivitas antioksidan tertinggi dengan nilai IC50 sebesar $131,85 \pm 0,71 \mathrm{ppm}$ diperoleh dari ekstraksi daun buangit dengan etanol 70\% selama 7 menit, namun secara statistik tidak berbeda nyata dengan aktivitas antioksidan hasil ekstraksi dengan etanol $60 \%$ selama 7 menit dengan nilai IC50 sebesar 132,02 $\pm 0,86 \mathrm{ppm}$. Hasil penelitian ini didukung oleh Anbazhagi et al. (2011) yang melaporkan bahwa ekstraksi daun buangit metode sokletasi dengan etanol $70 \%$ menghasilkan aktivitas antioksidan yang lebih tinggi 
dibandingkan dengan etanol 90\%. Waktu ekstraksi (lama paparan gelombang mikro) dan konsentrasi etanol (polaritas pelarut) yang tepat akan menghasilkan optimalnya proses ekstraksi dan mencegah terjadinya degradasi senyawa target (Veggi et al., 2013). Pemilihan polaritas yang tepat akan akan mempengaruhi kelarutan senyawa bioaktif ke pelarut, sedangkan efektifitasnya juga dipengaruhi lama kontak pelarut dengan bahan (waktu ekstraksi) sehingga didapatkan kombinasi yang tepat yang akan menghasilkan kadar senyawa bioaktif yang optimal. Senyawa bioaktif yang terekstrak akan mempengaruhi aktivitas antioksidan dari ekstrak tersebut.

Hubungan antara senyawa bioaktif dengan aktivitas antioksidan dapat diperkirakan dengan nilai koefisien korelasi pearson. Senyawa fenol ekstrak daun buangit memiliki koefisien korelasi pearson ( $\mathrm{r}$ ) sebesar $-0,83$ yang tergolong kategori kuat dan nilai koefisien determinasi (R) sebesar $69,12 \%$, sedangkan senyawa flavonoid dan vitamin C memiliki koefisien korelasi yang tergolong dalam kategori sangat lemah dengan nilai lebih dari $-0,01$. Hal ini menunjukkan bahwa adanya keterkaitan kuat antara total fenol dengan nilai IC50, dimana tingginya senyawa fenol yang terekstrak selaras dengan meningkatnya aktivitas antioksidan yang ditunjukan dari semakin rendahnya nilai IC50. Senyawa fenol ekstrak daun buangit berkontribusi sebesar $69,12 \%$ terhadap aktivitas antioksidannya, sedangkan 30,88\% aktivitas antioksidan ekstrak daun buangit dipengaruhi oleh senyawa selain fenol. Daun buangit mengandung senyawa fenol, flavonoid dan vitamin $\mathrm{C}$ yang dapat berperan sebagai antioksidan. Senyawa fenol merupakan antioksidan primer yang dapat menstabilkan radikal bebas dengan mendonasikan atom hidrogen pada radikal tersebut. Fenol dan flavonoid merupakan senyawa alami yang potensial berperan sebagai antioksidan dengan menangkal dan menghambat radikal bebas. Vitamin C merupakan vitamin yang dapat bereaksi dengan radikal bebas sehingga dapat berperan sebagai antioksidan, pengelat logam dan penangkap oksigen (oxygen scavenger) (Santoso, 2016). Buangit banyak digunakan sebagai obat tradisional. Buangit dapat digunakan sebagai obat antidiabetes, antikanker, meningkatkan sistem imun tubuh, antibakteri, dan lain sebagainya (Mishra et al., 2011).

Hasil penelitian menunjukkan bahwa ekstraksi dengan etanol $70 \%$ selama 7 menit menghasilkan aktivitas antioksidan tertinggi. Berdasarkan data penelitian, total fenol tertinggi dihasilkan dari ekstraksi dengan etanol 70\% selama 7 menit, sedangkan total flavonoid dan total vitamin $\mathrm{C}$ tertinggi dihasilkan dari ekstraksi dengan etanol $90 \%$ selama 7 menit. Hal ini menunjukan bahwa aktivitas antioksidan juga dipengaruhi oleh keberadaan senyawa bioaktif lainnya yang bersifat sebagai antioksidan yang terekstrak pada perlakuan tersebut, seperti senyawa alkaloid, saponin, tanin, glikosida dan $\beta$-karoten. Oleh sebab itu, ekstraksi dengan etanol 70\% selama 7 menit dinilai lebih efektif dalam mengekstraksi senyawa bioaktif yang ditunjukkan dengan aktivitas antioksidan tertinggi.

Ekstrak daun buangit pada penelitian ini yaitu sebesar $131,85 \pm 0,71$ ppm yang berarti tergolong dalam senyawa dengan aktivitas 
antioksidan sedang. Aktivitas antioksidan berdasarkan nilai IC50 dengan nilai berkisar antara 100-150 ppm termasuk dalam kategori senyawa dengan aktivitas antioksidan sedang (Bahriul et al., 2014). Hal ini didukung penelitian sebelumnya yang dilakukan oleh Widodo dan Pratiwi (2018) melaporkan bahwa ekstrak buangit (etanol 96\%) dari Palu, Indonesia memiliki nilai IC50 sebesar 189,455 ppm yang tergolong kategori lemah. Mibei et al. (2012) melaporkan bahwa buangit di Kenya memiliki aktivitas antioksidan yang lebih tinggi dibandingkan dengan penelitian ini yaitu sebesar 92,8\% dengan nilai IC50 sebesar 40 ppm. Perbedaan ini kemungkinan disebabkan oleh perbedaan letak geografis dari tempat tumbuh tanaman.

\section{KESIMPULAN DAN SARAN}

\section{Kesimpulan}

Berdasarkan hasil penelitian yang telah dilakukan, maka dapat disimpulkan sebagai berikut:

1. Interaksi antara konsentrasi etanol dan waktu ekstraksi berpengaruh nyata terhadap total flavonoid dan aktivitas antioksidan, namun tidak berpengaruh nyata pada total fenol dan vitamin $\mathrm{C}$ ekstrak daun buangit, sedangkan konsentrasi etanol dan waktu ekstraksi berpengaruh nyata terhadap total fenol, total flavonoid, total vitamin $\mathrm{C}$ dan aktivitas antioksidan ekstrak daun buangit.

2. Hasil penelitian menunjukkan bahwa kombinasi perlakuan terbaik pada ekstraksi daun buangit metode MAE adalah konsentrasi etanol $70 \%$ selama 7 menit yang dapat menghasilkan total fenol $18,52 \pm 0,64 \mathrm{mg}$
$\mathrm{GAE} / \mathrm{g}$, total flavonoid 19,28 $\pm 0,18 \mathrm{mg} \mathrm{QE} / \mathrm{g}$, total vitamin $\mathrm{C} 89,85 \pm 5,30 \mathrm{mg} \mathrm{AAE} / \mathrm{g}$ dan aktivitas antioksidan berdasarkan nilai IC50 sebesar $131,85 \pm 0,71 \mathrm{ppm}$.

\section{Saran}

Saran yang dapat diberikan yaitu perlu dilakukan penelitian lebih lanjut mengenai keberadaan senyawa bioaktif lainnya dalam ekstraksi daun buangit dengan metode MAE dan pengaruhnya terhadap aktivitas antioksidan ekstrak daun buangit.

\section{DAFTAR PUSTAKA}

Anbazhagi, T.K.K., G. Suguna dan A.J.A. Petrus. (2009). Studies on the Pharmacognostical and in Vitro Antioxidant Potential of Cleome gynandra Linn. Leaves. Research Paper Natural Product Radiance 9(2):151-157.

Ariviani, S. dan N.H.R. Parnanto. Kapasitas Antioksidan Buah Salak (Salacca Edulis Reinw) Kultivar Pondoh, Nglumut Dan Bali Serta Korelasinya Dengan Kadar Fenolik Total Dan Vitamin C. Jurnal Agritech 33(3): 324-333

Aulia, L.P. dan S.B. Widjarnako. (2018). Optimasi Proses Ekstraksi Daun Sirsak (Annona muricata L) Metode MAE (Microwave Assisted Extraction) dengan Respon Aktivitas Antioksidan dan Total Fenol. Jurnal Agroindustri Halal 4(1):79-87.

Bahriul, P., N. Rahman dan A.W.M. Diah. (2014). Uji Aktivitas Antioksidan Ekstrak Daun Salam (Syzygium polyanthum) Dengan Menggunanakan 1,1-Difenil-2-Pikrilhidrazil. Jurnal Akademi Kimia 3(3):143-149.

Chandradevan, M., S. Simoh, A. Mediani, N.H. Ismail, I.S. Ismail dan F. Abas. (2020). UHPLC-ESI-Orbitrap-MS Analysis of Biologically Active Extracts from Gynura procumbens (Lour.) Merr. and Cleome gynandra L. Leaves. Evidence-Based Complementary and Alternative Medicine 2020:1-14.

Delazar, A., L. Nahar, S. Hamedeyaz dan S.D. Sarker. (2012). Microwave -Assisted 
Extractuin in Natural Product Isolation. Di dalam Natural Products Isolation, Methods in Molecular Biology Vol. 864. S.D. Sarker dan L. Nahar (eds.). Springer Science \& Business Media, Berlin, p. 89-115.

Destandau, E., T. Michel dan C. Elfakir. (2013). Microwave-assisted Extraction. Di dalam Natural Product Extraction: Principles and Applications. M.A. Rostagno dan J.M. Prado (eds). The Royal Society of Chemistry, London, p. 113-155.

Gharekhani, M., M. Ghorbani dan N. Rasoulnejad. (2012). Microwave-Assisted Extraction of Phenolic and Flavonoid Compounds from Eucalyptus camaldulensis Dehn Leaves as Compared with Ultrasound-Assisted Extraction. Journal of Latin American Applied Research 42:305-310.

Guntarti, A., J. Annisa, M. Mughniy san F. Rizqi. Effect of Regional Variation on The Total Flavonoid Level of Ethanol Extract of Mangosteen (Gracinia mangostana) Peels. Jurnal Kedokteran dan Kesehatan Indonesia 8(2):136-143).

Hanani, E., A. Mun'im dan R. Sekarini. (2005). Identifikasi Senyawa Antioksidan Dalam Spons Callyspongia sp Dari Kepulauan Seribu. Majalah Ilmu Kefarmasian 2(3):127133.

Hismath, I., W.M. Wan Aida dan C.W. Ho. (2011). Optimization of extraction conditions for phenolic compounds from neem (Azadirachta indica) leaves. International Food Research Journal 18: 931-939.

Jain, T., V. Jain, R. Pandey, A. Vyas, S.S. Shukla. (2009). Microwave Assisted Extraction for Phytoconstituents - An Overview. Asian Journal Research Chemistry 1(2):19-25.

Jiménez-Aguilar, D.M., M.A. Grusak. (2015). Evaluation of minerals, phytochemical compounds and antioxidant activity of Mexican, Central American, and African green leafy vegetables. Plant Foods Hum Nutr 70:357-364.

Kamaluddin, M.H., M. Lutfi, dan Y. Hendrawan. (2014). Analisa Pengaruh Microwave Assisted Extraction (MAE) Terhadap Ekstraksi Senyawa Antioksidan Catechin Pada Daun Teh Hijau (Camellia sinensis) (Kajian Waktu Ekstraksi Dan Rasio Bahan:Pelarut). Jurnal Keteknikan Pertanian Tropis dan Biosistem 2(2):147-155.
Kristanti, Y., I W.R. Widarta dam I D.G.M. Permana. (2019). Pengaruh Waktu Ekstraksi dan Konsentrasi Etanol Menggunakan Metode Microwave Assisted Extraction (MAE) Terhadap Aktivitas Antioksidan Ekstrak Rambut Jagung (Zea Mays L.). Jurnal Ilmu dan Teknologi Pangan 8(1): 94-103.

Kwarteng, A.O., J. Abogoom, R.A. Amoahm, D. Nyadanu. T. Ghunney. K.C. Nyam, J.Z. Ziyaaba, E.O. Danso. D.D. Asiedu. Dan T. Whyte. (2018). Current Knowledge and breesing perspectives for the spider plant (Cleome gynandra L.): A Potential for Enhanced Breeding of Plant in Africa. Genetic resources and Crop Evolution 65(5):1529-1550.

Mibei, E.K., N.K.O. Ojijo, S.M. Karanja dan J.K. Kinyua. (2012). Phytochemical and Antioxidant Analysis of Methanolic Extract of Four African Indegenous Leafy Vegetables. Journal of Analysis Food Science and Technology 13(1):37-42.

Mishra, S.S. S.K. Moharana dan M.R. Dash. (2011). Review on Cleome gynandra. International Journal of Research in Pharmacy and Chemistry 1(3):681-688.

Moyo, S. M., E. Kayitesi, V. Mavumengwana dan N. E. Malada. (2016). Effect of Cooking and Drying on the Total Phenolic, Total Flavonoid Content, Antioxidant and Antibacterial Activity of Cleome gynandra (Spider Plant). International Conference on Advance in Science, Engineering, Technology and Natural Resources 16:138-144.

Patpoutsis, K., Q.V. Vuong, P. Pristijono, J.B. Golding, M.C. Bowyer, C.J. Scarlett dan C.E. Stathopoulos. (2016). Enhancing the Total Phenolic Content and Antioxidants of Lemon Pomace Aqueous Extracts by Applying UV-C Irradiation to the Dried Powder. Journal Foods 5(55):1-10.

Prayitno, S.A., J. Kusnadi, E.S. Murtini. (2016). Antioxidant activity of red betel leaves extract (Piper crocatum Ruiz and Pav.) by different concentration of solvents. Journal of Pharmaceutical, Biological and Chemical Science 7(5):1836-1843.

Sakanaka, S., Y. Tachibana., dan Y. Okada. (2005). Preparation and antioxidant properties of extracts of japanese persimo leaf tea (kakinocha-cha). Food Chemistry 89: 569575 . 
Santoso, U. 2017. Antioksidan Pangan. Gadjah Mada University Press. Yogyakarta.

Sogbohossou, E. O. Dêêdi, D. Kortekaa, E.G. Achigan-Dako, P. Maundu dan T. Stoilova. (2019). Association between vitamin content, plant morphology and geographical origin in a worldwide collection of the orphan crop Gynandropsis gynandra (Cleomaceae). Journal Planta 250:933-974.

Stoica, R., S. Velea, L. Ilie, M. Calugareanu, S.B. Ghimis dan R. Ion. (2013). The Influence of Ethanol Concentration on the Total Phenolics and Antioxidant Activity of Scenedesmus Opoliensis Algal Biomass Extracts. Revista de Chimie-Bucharest 63 (3): 304-306.

Veggi, P.C., J. Martinez dan M.A.A. Meireles. (2013). Fundamentals of Microwave Extraction. Di dalam Microwave-assisted Extraction for Bioactive Compounds: Theory and Practice. Food Engineering Series 4. F. Chemat and G. Cravotto (eds.). Springer Science \& Business Media, New York, p. 1552.
Verdiana, M., I W.R. Widarta dan I D.G.M. Permana. (2018). Pengaruh Jenis Pelarut Pada Ekstraksi Menggunakan Gelombang Ultrasonik Terhadap Aktivitas Antioksidan Ekstrak Kulit Buah Lemon (Citrus limon (Linn.) Burm F.). Ilmu dan Teknologi Pangan 7(4):213-222.

Widodo, A. dan R. Pratiwi. (2018). Phytochemical Screening, Total Flavonoid, Antioxidant Activity, And Toxicity of Ethanol Extract Cleome gynandra L. Herb. Journal Islamic Pharmacy 3(2):41-50.

Widyawati, P.S. (2005). Potensi Daun Kemangi (Ocium basilicum Linn) Sebagai Penangkap Radikal Bebas DPPH (2,2-diphenyl-1pycrylhidrazil radical). Jurnal Agritech 25(3):137-142.

Zecović, Z., J. Vladić, S. Vidović, D. Adamović dan B. Pavlića. (2016). Optimization of Microwave-Assisted Extraction (MAE) of Coriander Phenolic Antioxidants - Response Surface Methodology Approach. Journal Science Food Agrictech 96(13):4613-4622. 